\title{
Akdeniz Bölgesi doğal Celtis australis genotiplerinin çimlenme özelliklerine ekim öncesi uygulamalarmn etkileri
}

\section{Effect of pre-sowing treatments on germination characteristics of Celtis australis genotypes native to Mediterranean Region}

\author{
Ayşe DURAK@, Osman KARAGÜZEL®i \\ Akdeniz Üniversitesi, Mimarlık Fakültesi, Peyzaj Mimarlı̆ğ Bölümü, 07070, Antalya, Türkiye \\ Sorumlu yazar (Corresponding author): A. Durak, e-posta (e-mail): aysedurak@akdeniz.edu.tr \\ Yazar(lar) e-posta (Author e-mail): okaraguzel@akdeniz.edu.tr
}

\section{MAKALE BİLGİSİ}

Alınış tarihi 11 Eylül 2019

Düzeltilme tarihi 31 Ekim 2019

Kabul tarihi 31 Ekim 2019

\section{Anahtar Kelimeler:}

Celtis australis

Genotip

Tohum özelliği

Fizyolojik dormansi

Stratifikasyon

\section{ÖZ}

Son yıllarda bitkisel peyzaj tasarımında doğal bitki türlerinin kullanımına yönelik talepler artmıştır. Celtis australis L. Akdeniz Bölgesi kıyı kesiminde bitkisel tasarım amaçlı kullanım potansiyeli yüksek olan ağaç türlerinden biridir. Bu çalışma Antalya'nın Serik ilçesinde bulunan C. australis genotiplerinin çimlenmesine ekim öncesi işlemlerin etkisinin belirlenmesi amacıyla gerçekleștirilmiștir. Bu amaçla beș genotipten alınan tohumlar üzerinde iki deneme yürütülmüştür. Birinci denemede meyve eti uzaklaştırılmış ve uzaklaştırılmamış tohumların çimlenme özelliklerine genotip ve oda sıcaklığında muhafaza sürelerinin $(0,15,30,45$ ve 60 gün) etkisi incelenmiștir. İkinci denemede ise genotiplerin çimlenme özelliklerine 1slak katlama (stratifikasyon) süresi $\left(+4^{\circ} \mathrm{C}^{\prime}\right.$ de 0,60 ve 90 gün) ve çimlenme-testi ortamının (torf ve kağıt havlu) etkileri araştırılmıștır. Sonuçlar, birinci denemedeki hiçbir uygulama etkisinde çimlenmenin gerçekleşmediğini göstermiştir. İkinci deneme ile ilgili sonuçlar ise katlama süresi, genotip ve çimlenme-testi ortamı ile interaksiyon etkilerinin çimlenme özelliklerinde istatistiksel anlamda önemli farklılıklarla sonuçlandığını ortaya koymuştur. Katlama süresinin artışılyla çimlenme oranları artmış, bu oranlar genotiplere göre farklılık göstermiş ve en uygun çimlenme özellik değerleri torf çimlenme-testi ortamında kaydedilmiştir. En yüksek çimlenme oranı (\%74.66), 90 gün süreyle $+4^{\circ} \mathrm{C}$ 'de katlamaya alınan ve torf çimlenme-testi ortamında çimlendirilen GT5 genotipine ait tohumlardan elde edilmiştir. Bu sonuçlar Akdeniz kıyı kesimi C. australis genotipleri tohumlarında fizyolojik dormansinin kanıtı olarak değerlendirilmiştir.

\section{ARTICLE INFO}

Received 11 September 2019

Received in revised form 31 October 2019

Accepted 31 October 2019

\section{Keywords:}

Celtis australis

Genotype

Seed characteristics

Physiological dormancy

Stratification

\section{ABSTRACT}

In recent years, the demands for the use of native plant species in planting design have increased. Celtis australis L. is one of the species with high potential for use planting design in Mediterranean. This study was carried out to determine the effect of pre-sowing treatments on germination of $C$. australis genotypes native to Serik district of Antalya and two experiments were conducted on the seeds harvested from five genotypes. In the first experiment, the effects of genotype and storage time $(0,15,30,45$ and 60 days) at room temperatures on germination characteristics of the seeds with or without fleshy pericarp tissues were determined. In the second experiment, the effects of stratification time $\left(0,60\right.$ and 90 days at $\left.+4^{\circ} \mathrm{C}\right)$ and germination-test medium (peat and paper towel) on germination characteristics of genotypes were investigated. Results from first experiment indicated that there was no germination in any of treatment used in the experiment. The results of the second experiment revealed that stratification time, genotype and germination-test medium, and interactions resulted in significant differences in germination characteristics of $C$. australis. Germination rates increased with increasing stratification time and differed according to genotypes, and the most adequate germination characteristics were recorded in peat germination-test medium. The highest germination rate $(74.66 \%)$ was recorded for the seeds of GT5 genotype which were stratified for 90 days at $+4^{\circ} \mathrm{C}$ and germinated in peat germination-test medium. Results were considered as verification of physiological dormancy in seeds of $C$. australis genotypes native to Mediterranean. 


\section{Giriş}

Son yıllarda ekolojik avantajları ve bitkisel tasarımda sürdürülebilirliğin kilit unsurları olarak görülmeleri doğal türlere olan ilgi ve talebi beklenenden büyük boyutlara ulaştırabilmiştir (Brzuszek ve Harkess 2009). Kullanım potansiyeli yüksek bazı türler, Baskin ve Baskin (2014)'in bildirdiği gibi var oldukları ekolojik koşullara uyum sağlamak için mükemmel biyolojik stratejiler geliştirmiş olabilmektedirler. Ancak tohum dormansisi gibi stratejiler, kültür koşullarında programlanmak zorunda olan işlemler için önemli bir engel haline gelebilmekte ve bu engellerin aşılması fidan üretiminde maliyetler ve ürün programlama açısından büyük önem taşıyabilmektedir (von Henting 1998).

Celtis australis L. Cannabaceae (eskiden Ulmaceae) familyasından, 20-25 m boyunda, yuvarlak tepeli, uzun boylu, seyrek dallı, kışın yaprağını döken bir ağaç türüdür (Kayacık 1977; Crivellaro ve Schwiengruber 2013). Bu tür Kuzey Afrika, Güney Avrupa, Batı Asya'da doğal yayılış göstermekte (Idzojtic 2019) ve Türkiye'de Kuzey, Bat1 ve Güney Anadolu'nun pek yüksek olmayan (50-700 metre) kesimlerinde görülmektedir (Yaltırık ve Efe 2000). C. australis, Akdeniz kıyı kesimi için çınar, sığla ve dişbudak gibi yaprak döken türlere alternatif oluşturabilecek niteliklere sahiptir.

C. australis biyolojik ve endüstriyel özellikleri ile ilgi çekmiş ve çoğaltılması ile ilgili çok sayıda bilimsel çalışma gerçekleştirilmiştir. Ancak uzun yıllardır bilinmektedir ki bitki türlerinin çimlenme özelliklerinde genetik ve çevresel faktörlere ve hatta çimlenme testi için kullanılan ortamlara bağlı olarak büyük farklılıklar ortaya çıkabilmektedir (Elias ve ark. 2012; Baskin ve Baskin 2014). Bazı odunsu bitki türlerinin çimlenme özelliklerinin yalnızca genotip ve temel çevresel faktörlere göre değil, bitki üzerinde tohum sağlanan meyvelerin bulunduğu konuma göre bile farklılaşabildiği ortaya konmuştur (Nielsen 1988; Copeland ve McDonald 2001).

Hartmann ve ark. (2002) Celtis türlerinin birçoğunda kullanılan tohumların sonbaharda ön işlemsiz ekildiğini, ilkbaharda yapılacak ekimlerde ise iki ya da üç ay katlama $\left(+4^{\circ} \mathrm{C}\right)$ yapılması gerektiğini, Dirr ve Heuser (2006) ise Celtis türlerinin tohumlarında 3 ay katlama yapmanın faydalı olacağını belirtmişlerdir. Yücedağ ve Gültekin (2008), ekim zamanları ve katlama işlemlerinin çimlenme oranları üzerinde önemli bir etkiye sahip olduğunu, uygun soğuk-1slak katlama süresinin 3090 gün, katlama uygulanmayan tohumlar için uygun ekim zamanının ise Kasım, Aralık ve Ocak ayları olduğunu bildirmişlerdir. Takos ve Efthimiou (2002), C. australis türünün tohumlarının fidanlık koşullarında yüksek oranda çimlendiğini (\%76) laboratuvar koşullarında ise bu oranın çok düşük (\%16) olduğunu belirtmişlerdir. Güney ve ark. (2018) ise Trabzon İlinde yetişen genotiplerle gerçekleştirdikleri çalışmada, 120 gün oda sıcaklığında muhafaza edilen $C$. australis tohumlarının Mart ayında ekilmesi ile ön işlemlere gerek kalmadan iyi sonuçlar elde edildiğini belirlemişlerdir. APAT (2003) C. australis'in çimlenme oranının \%50-90 arasında değiştiğini bildirmekte ve ön işlem uygulanmayan tohumların sonbaharda, 8-12 hafta soğuk katlamada tutulan tohumların ise ilkbaharda ekilebileceğini önermektedir. Ballesteros ve ark. (2015)'da benzer önerilerde bulunmaktadırlar. Pipinis ve ark. (2018) ise $C$. australis türü tohumlarında dormansinin varlığından bahsederek kış koşullarına maruz kalan tohumların dormansi durumunun üstesinden gelebildiklerini belirtmişlerdir. Singh ve ark. (2009), taze tohumlardan 18 ay oda koşullarında muhafaza edilen tohumlara göre daha yüksek çimlenme oranları elde edildiğini bildirmektedirler. Yine Singh ve ark. (2006), C. australis türünün tohum ve çimlenme özelliklerinin bulunduğu yükseltiye bağlı olarak değiştiğini tespit etmişlerdir. Yapılan çalışmalar $C$. australis'in farkl1 ekolojilerde yer alan genotiplerinin çimlenme özellikleri açısından farklı tepkiler verebileceğini göstermektedir. İngilizce adlarından birinin Akdeniz ile ilişkili olmasına karşın (Mediterranean hackberry) Akdeniz kıyı kesimindeki $C$. australis genotipleri tohumlarının çimlenme özellikleri ile ilgili çalışmalar son derece sınırlı ve kaynakların bir kısmı tavsiye niteliğindedir (Ballesteros ve ark. 2015).

$\mathrm{Bu}$ sebeple, Antalya ili Serik ilçesinde doğal olarak yetişmekte olan $C$. australis genotiplerinin çimlenme özelliklerine ekim öncesi işlemlerin etkisinin belirlenmesi bu çalışmanın temel amacını oluşturmuştur.

\section{Materyal ve Yöntem}

$\mathrm{Bu}$ çalışmada bitkisel materyal olarak Antalya ili Serik ilçesi kırsal alanlarından 2013 yılı Ekim ayında C. australis türünün tipik form ve morfolojik özelliklerine uygun olarak seçilmiş olan 5 genotipten hasat edilen meyve ve tohumlar kullanılmıştır. Çalışma gözlem, ölçüm ve deneme düzenlenmeleri bakımından üç temel aşamadan oluşmuştur.

\subsection{Tohum özelliklerinin belirlenmesi}

Çalışmanın bu aşamasında; seçilmiş beş genotipin her birinin tohumlarından üç tekerrür halinde 100 adet meyve eti tamamen ayıklanmış tohum tesadüf kurallarına uygun olarak ayrılmış ve tohumlarda çap ve ağırlık değerleri belirlenmiştir. $\mathrm{Bu}$ değerlerin istatistiksel analizi, genotipten oluşan tek faktörlü tesadüf parselleri deneme deseni esas alınarak yapılmıştır.

\subsection{Genotip, tohum muhafaza şekli ve süresinin çimlenme özelliklerine etkisinin belirlenmesi}

$\mathrm{Bu}$ amaçla, deneme için 5 genotipten sağlanan tohumların yarısı meyve etli, diğer yarısı ise meyve etlerinden ayrılarak 0 , $15,30,45,60$ gün süreyle karanlık, serin ve sicaklığı ortalama $23.4 \pm 1.8^{\circ} \mathrm{C}$ olan bir ortamda muhafaza edilmiştir. Meyve etli muhafaza edilen tohumların meyve eti çimlenme testlerinden bir gün önce ayıklanmıştır. Çimlenme testleri için $12 \mathrm{~cm}$ çapında plastik petri kapları kullanılmış, kapların tabanına iki kat kağıt havlu yerleştirilmiş ve her bir kaba 25 adet tohum konarak $20 \mathrm{ml}$ saf su ilave edilmiştir. Çimlenme testleri $20^{\circ} \mathrm{C}$ 'ye ayarlanmış iklimlendirme dolabında gerçekleştirilmiş ve Elias ve ark. (2012)'nın bildirimleri dikkate alınarak 30 gün sürdürülmüştür. Deneme, genotip (GT1, GT2, GT3, GT4 ve GT5), muhafaza şekli (meyve etli, meyve eti ayıklanmış) ve muhafaza süresi $(0,15,30,45,60$ gün) uygulamalarından oluşan üç faktörlü ve üç tekerrürlü tesadüf parselleri deneme desenine göre kurulmuş ve her yineleme 25 tohum konmuş bir petri kabından oluşmuştur.

\subsection{Genotip, katlama (stratifikasyon) süresi ve çimlenme-testi ortamının çimlenme özelliklerine etkisinin belirlenmesi}

$\mathrm{Bu}$ denemede 5 genotipten hasat edilerek 0, 60 ve 90 gün soğuk $\left(+4^{\circ} \mathrm{C}\right)$-1slak katlamada tutulan tohumların, torf ve kâğıt havlu olmak üzere iki farklı çimlenme-testi ortamında çimlenme özellikleri saptanmıştır. Ekim ayında hasat edilen tohumlar pamuklu torbalar içine konmuş, torbalar $5 \mathrm{~cm}$ kalınlığında torf doldurulmuş olan plastik kaba yerleştirilip üzeri yine $5 \mathrm{~cm}$ kalınlığında torf ile kapatılmış ve ortam su göllenmesi olmayacak şekilde ıslatılmıştır. Hazırlanan katlama kabı soğuk 
1slak katlama işlemi için $+4^{\circ} \mathrm{C}^{\prime}$ ye ayarlanmış buzdolabına yerleştirilmiştir.

Çimlenme-testi ortamı olarak $12 \mathrm{~cm}$ çapındaki plastik petri kaplarının tabanına iki kat kâğıt havlu veya $0.5 \mathrm{~cm}$ kalınlığında çimlenme torfu yerleştirildikten sonra $20 \mathrm{ml}$ saf su eklenmiş ve her bir petri kabına 25 adet tohum konmuştur. Çimlenme testleri $20^{\circ} \mathrm{C}$ 'ye ayarlanmış iklimlendirme dolabında gerçekleştirilmiş ve 27 gün sürdürülmüştür. Deneme, genotip (GT1, GT2, GT3, GT4, GT5), katlama süresi (0, 60 ve 90 gün) ve çimlenme-testi ortamı (kağıt havlu ve torf) uygulamalarından oluşan üç faktörlü ve üç tekerrürlü tesadüf parselleri deneme desenine göre kurulmuş ve her yineleme 25 tohum konmuş bir petri kabından oluşmuştur.

Denemeler süresince kök ucu $2 \mathrm{~mm}$ uzunluğa ulaşmış tohumlar çimlenmiş kabul edilmiş ve her gün çimlenen tohum sayıları alınmış, sürgün ve kök kuru ağırlık değerleri ise test sürelerinin sonunda saptanmıştır. Karagüzel (2003)'in belirttiği şekilde çimlenme oranı test süresi sonunda ekilen ve çimlenen tohumlar oranlanarak, ortalama çimlenme süresi (MGT) ise $(\mathrm{MGT})=\sum \mathrm{Ti} \mathrm{Ni} / \sum \mathrm{Ni}$ formülü ile hesaplanmış, burada Ti: ekimden sonraki kaçıncı günde gözlem yapıldığını, Ni: gözlemin yapıldığı günde çimlenen tohum sayısını ifade etmektedir. Sürgün ve kök kuru ağırlıkları ise çimlenme denemesinin tamamlanmasından sonra alınan sürgün ve kök örnekleri kurutma dolabında $70^{\circ} \mathrm{C}$ 'de 5 gün süreyle tutulduktan sonra saptanmıştır.

\subsection{Veri analizi}

Veri elde edilebilen denemeler ve uygulamalar için grafik oluşturulması Microsoft Office Excel ortamında ve istatistiksel analizler SPSS 17 programında gerçekleştirilmiş, ortalamaların karşılaştırılması için ise $\% 5$ önem düzeyinde Duncan testi kullanılmıştır.

\section{Bulgular}

\subsection{Tohum özellikleri}

Saptanan tohum çapı ve tohum ağırlığı değerlerinin analiz sonuçları, her iki özelliğin de genotiplere göre istatistiksel anlamda önemli $(P<0.001)$ farklılıklar gösterdiğini ortaya koymuştur (Çizelge 1). Genotiplerin ortalama tohum çap1 değerleri 5.37-6.26 mm arasında, tohum ağırlığ değerleri ise 0.14-0.20 mg arasında değişim göstermiş, en yüksek tohum çap1 $(6.26 \mathrm{~mm})$ ve ağırlığ $1(0.20 \mathrm{mg})$ değerleri GT4 genotipinde ölçülmüştür (Çizelge 1).

Çizelge 1. C. australis genotiplerinde bazı temel tohum özellikleri. Table 1. Certain basic seed characteristics of $C$. australis genotype.

\begin{tabular}{lcc}
\hline Genotip & Tohum çapı $(\mathrm{mm})$ & Tohum ă̆ırlı̆̆ $(\mathrm{mg})$ \\
\hline GT1 & $5.44 \mathrm{~cd}^{\mathrm{z}}$ & $0.14 \mathrm{c}$ \\
GT2 & $5.74 \mathrm{~b}$ & $0.17 \mathrm{~b}$ \\
GT3 & $5.37 \mathrm{~d}$ & $0.14 \mathrm{c}$ \\
GT4 & $6.26 \mathrm{a}$ & $0.20 \mathrm{a}$ \\
GT5 & $5.57 \mathrm{c}$ & $0.16 \mathrm{~b}$ \\
Önemlilik (P değeri) & & \\
\hline Genotip (GT): & $<0.001$ & $<0.001$ \\
\hline
\end{tabular}

3.2. Genotip, tohum muhafaza şekli ve süresinin çimlenme özelliklerine etkisi

Ekim ayında hasat edilip meyve etli ve meyve etsiz olarak $0,15,30,45$ ve 60 gün süre ile oda sicaklığında $\left(23.4 \pm 1.8^{\circ} \mathrm{C}\right)$ muhafaza edilerek çimlenme testi yapılan $C$. australis genotipleri tohumlarında meyve etlilik durumu ve muhafaza süresinin çimlenme üzerinde etkisinin olmadığı ve hiçbir uygulamada tohumların çimlenmediği belirlenmiş̧tir.

\subsection{Genotip, katlama (stratifikasyon) süresi ve çimlenme-testi ortamının çimlenme özelliklerine etkisi}

Varyans analizi sonuçları, katlama süresi $(P \leq 0.001)$, genotip $(P \leq 0.001)$ ve çimlenme-testi ortamının $(P \leq 0.01)$ çimlenme oranları üzerinde önemli etkileri olduğunu ortaya koymuştur (Çizelge 2). Çimlenme oranları ayrıca katlama süresi $\mathrm{x}$ genotip $(P \leq 0.001)$, genotip x çimlenme-testi ortamı $(P \leq 0.01)$ ve katlama süresi $\mathrm{x}$ genotip $\mathrm{x}$ çimlenme-testi ortamı interaksiyon etkilerine $(P \leq 0.001)$ bağlı olarak da önemli farklılıklar göstermiştir (Çizelge 2). Çimlenme oranları ana etkiler düzeyinde incelendiğinde; ortalama en yüksek çimlenme oranının 90 gün süreyle katlamada kalan tohumlardan elde edildiği, çimlenme oranlarının katlama süresi kısaldıkça azaldığ 1 ve katlama uygulaması yapılmayan tohumlarda çimlenmenin gerçekleşmediği görülmektedir (Şekil 1). Bunun yanı sıra ortalama çimlenme oranları genotiplere göre de önemli düzeyde farklılık göstermiş, en yüksek ortalama çimlenme oranları aralarında istatistiksel anlamda fark olmaksızın GT4 ve GT5 genotiplerinde, en düşük ortalama çimlenme oranı ise GT2 genotipinin tohumlarında belirlenmiştir (Çizelge 2, Şekil 2). Şekil 3'de görüldüğü gibi ana etki düzeyinde ortalama çimlenme oranları çimlenme-testi ortamına göre de farklılık göstermiş, torf ortamından kağıt havlu çimlenme-testi ortamına göre daha yüksek çimlenme oranları elde edilmiştir. Üçlü interaksiyon düzeyinde en yüksek çimlenme oranı (\%74.67), 90 gün katlamada kalan ve torf çimlenme-testi ortamına konan GT5 genotipinin tohumlarından elde edilmiş, bu genotipi \%73.33 çimlenme oranıyla aynı koşullarda bulunan GT4 genotipi tohumları izlemiştir (Çizelge 3).

Çizelge 2'de görüldüğü gibi ortalama çimlenme süresi üzerine katlama süresi $(P \leq 0.01)$, genotip $(P \leq 0.001)$ ve çimlenme-testi ortamının $(P \leq 0.001)$ etkisinin istatistiksel anlamda önemli, bu faktörlerin ikili ve üçlü interaksiyonlarının etkilerinin ise önemli olmadığı belirlenmiştir. Ortalama çimlenme süresine katlama süresinin ana etkisi incelendiğinde; en kısa ortalama çimlenme süresine sahip tohumların ise 90 gün süreyle $+4^{\circ} \mathrm{C}$ 'de katlamada kalan tohumlar olduğu görülmektedir (Şekil 1). Analizler ortalama çimlenme süreleri açısından genotipler arasında önemli farklar bulunduğunu ve GT4 genotipi tohumlarının en k1sa sürede, GT1 genotipi tohumlarının ise en uzun sürede çimlenen tohumlar olduğunu ortaya koymuştur (Şekil 2). Çimlenme-testi ortamı bağlamında ise torf ortamında bulunan tohumların kağıt havlu ortamında bulunanlardan daha kısa sürede çimlendiği belirlenmiştir (Şekil 3). Sonuçlar üçlü interaksiyon düzeyinde incelendiğinde; uygulamalarda ortalama çimlenme sürelerinin 8.62 gün ile 23.50 gün arasında değiştiği görülmektedir (Çizelge 3). 60 gün katlamada kalan torf çimlenme-testi ortamındaki GT1 genotipi tohumlarının diğerlerine kıyasla daha uzun sürede çimlendiğ belirlenmiştir. En kısa ortalama çimlenme süresi ise 8.62 gün ile 90 gün katlamadan sonra torf çimlenme-testi ortamına ekilmiş olan GT4 genotipi tohumlarında saptanmıştır (Çizelge 3). 
Çizelge 2. C. australis tohumlarının çimlenme özelliklerine katlama (stratifikasyon) süresi, genotip ve çimlenme-testi ortamının etkisine ilişkin varyans analizi (ANOVA) sonuçları.

Table 2. ANOVA results on the effects of stratification time, genotype and germination-test medium on germination characteristics of $C$. australis seeds.

\begin{tabular}{|c|c|c|c|c|c|}
\hline \multirow[b]{2}{*}{ Varyasyon Kaynağ 1} & \multirow[b]{2}{*}{$\mathrm{SD}$} & \multicolumn{4}{|c|}{ Hata Kareler Ortalaması } \\
\hline & & $\begin{array}{c}\text { Çimlenme oranı } \\
(\%)\end{array}$ & $\begin{array}{l}\text { Ortalama çimlenme süresi } \\
\text { (gün) }\end{array}$ & $\begin{array}{c}\text { Kök kuru ağırlığ } 1 \\
\text { (mg/bitki) }\end{array}$ & $\begin{array}{l}\text { Gövde kuru ağırlığ } \\
\text { (mg/bitki) }\end{array}$ \\
\hline Katlama süresi (KS) & 2 & $12186.311 * * *$ & $162.951 * *$ & $55.025 * * *$ & $5586.593 * * *$ \\
\hline Genotip (G) & 4 & $5785.156 * * *$ & $136.072 * * *$ & $12.796 * * *$ & $377.552 * * *$ \\
\hline Çimlenme-testi ortamı (ÇTO) & 1 & $284.444 * *$ & $57.992 * * *$ & $59.146 * * *$ & 0.725 ÖD \\
\hline $\mathrm{KS} x \mathrm{G}$ & 8 & $1530.756 * * *$ & 9.520 ÖD & $5.510 * * *$ & $382.384 * * *$ \\
\hline KSxÇTO & 2 & 105.244 ÖD & 6.135 ÖD & $15.821 * * *$ & 17.086 ÖD \\
\hline GxÇTO & 4 & $151.556 * *$ & 4.603 ÖD & $8.673 * * *$ & 35.926 ÖD \\
\hline KSxGxÇTO & 8 & $185.689 * * *$ & 6.366 ÖD & $5.335 * * *$ & 17.752 ÖD \\
\hline Hata & 60 & 39.289 & 3.309 & 0.258 & 23.156 \\
\hline
\end{tabular}

ÖD, *,**,***: Önemli değil, sırasıyla $P \leq 0.05,0.01$ ve $\leq 0.001$ düzeyinde önemli.
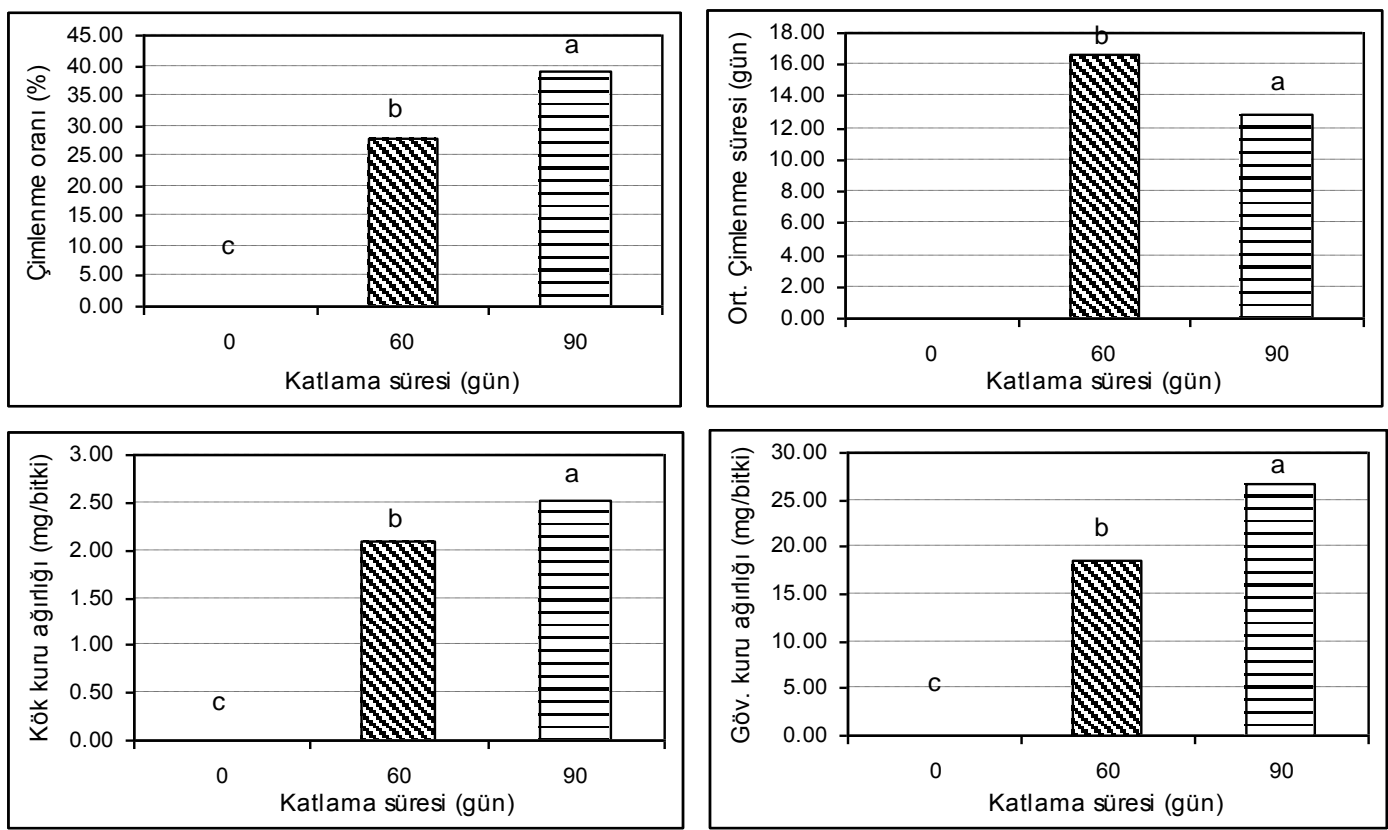

Şekil 1. C. australis tohumlarının çimlenme özelliklerine katlama (stratifikasyon) süresinin ana etkisi. Her bir özellik grafiğinde farklı harflerle gösterilen ortalamalar \%5 önem düzeyindeki Duncan testine göre birbirinden farklıdır.

Figure 1. The main effect of stratification time on germination characteristics of $C$. australis seeds. Means indicated by different letters in each characteristic graph are significantly different at the $5 \%$ level according to Duncan's multiple range.

Kök kuru ağırlığı üzerinde katlama süresi $(P \leq 0.001)$ genotip $(P \leq 0.001)$ ve çimlenme-testi ortamı $(P \leq 0.001)$ ile bu faktörlerin ikili ve üçlü interaksiyonları etkilerinin $(P \leq 0.001)$ istatistiksel anlamda önemli olduğu saptanmıştır (Çizelge 2). Katlama süresi ana etkisi bağlamında katlama süresi arttıkça ortalama kök kuru ağırlık değerlerinin arttığı belirlenmiş, en yüksek ortalama kök kuru ağırlık değerleri 90 gün süreyle $+4^{\circ} \mathrm{C}$ 'de katlamaya alınan tohumlarda kaydedilmiştir (Şekil 1). Genotip ana etkisi düzeyinde ise en küçük ortalama kök kuru ağırlık değerleri aralarında istatistiksel anlamda fark olmaksızın GT1, GT2 ve GT3 genotiplerinde ölçülmüş, GT4 ve GT5 genotiplerinde bu değerler artmış ve en yüksek ortalama değerler GT4 genotipinde saptanmıştır (Şekil 2). Torf çimlenme-testi ortamının kök kuru ağırlığı bakımından kâğıt havlu çimlenme-testi ortamına kıyasla daha yüksek değere sahip olduğu Şekil 3'de görülmektedir. Üçlü interaksiyon düzeyinde; 6.21 ve $6.95 \mathrm{mg}$ ile en yüksek kök kuru ağırlığ ve 90 gün süreyle katlamada tutularak torf çimlenme-testi ortamına ekilen GT4 genotipi tohumlarında saptandığ 1 görülmektedir (Çizelge 3). En küçük ortalama kök kuru ağırlığ 1 değeri ise $0.22 \mathrm{mg}$ ile 60 gün süre ile katlamada tutularak kağıt havlu çimlendirme-testi ortamına ekilen GT1 genotipi tohumlarında belirlenmiştir (Çizelge 3).

Gövde kuru ağırlığının, katlama süresi $(P \leq 0.001)$, genotip $(P \leq 0.001)$ ve bu iki faktörün interaksiyon $(P \leq 0.001)$ etkisiyle önemli farklılıklar gösterdiği saptanmıştır (Çizelge 2). 90 gün katlamada kalan tohumların 60 gün katlamada kalanlara kıyasla daha yüksek ortalama gövde kuru ağırlığına sahip olduğu belirlenmiştir (Şekil 1). Ortalama değerler GT4 genotipinin en yüksek, GT2 genotipinin ise en düşük ortalama gövde kuru ağırlığına sahip olduğunu göstermektedir (Şekil 2). Analiz sonuçları, ortalama gövde kuru ağırlığına çimlenme-testi ortamı ana etkisinin istatistiksel anlamda önemli olmadığını ortaya koymuştur (Şekil 3). Üçlü interaksiyonu düzeyinde, en yüksek gövde kuru ağırlık değeri $37.28 \mathrm{mg}$ ile 60 gün katlamada kaldıktan sonra torf çimlenme-testi ortamına ekilen GT4 genotipi tohumlarında, en düşük gövde kuru ağırlık değeri ise $13.83 \mathrm{mg}$ ile 60 gün katlamada kaldıktan sonra torf çimlenme testi ortamına ekilen GT1 tohumlarında tespit edilmiştir (Çizelge 3). 

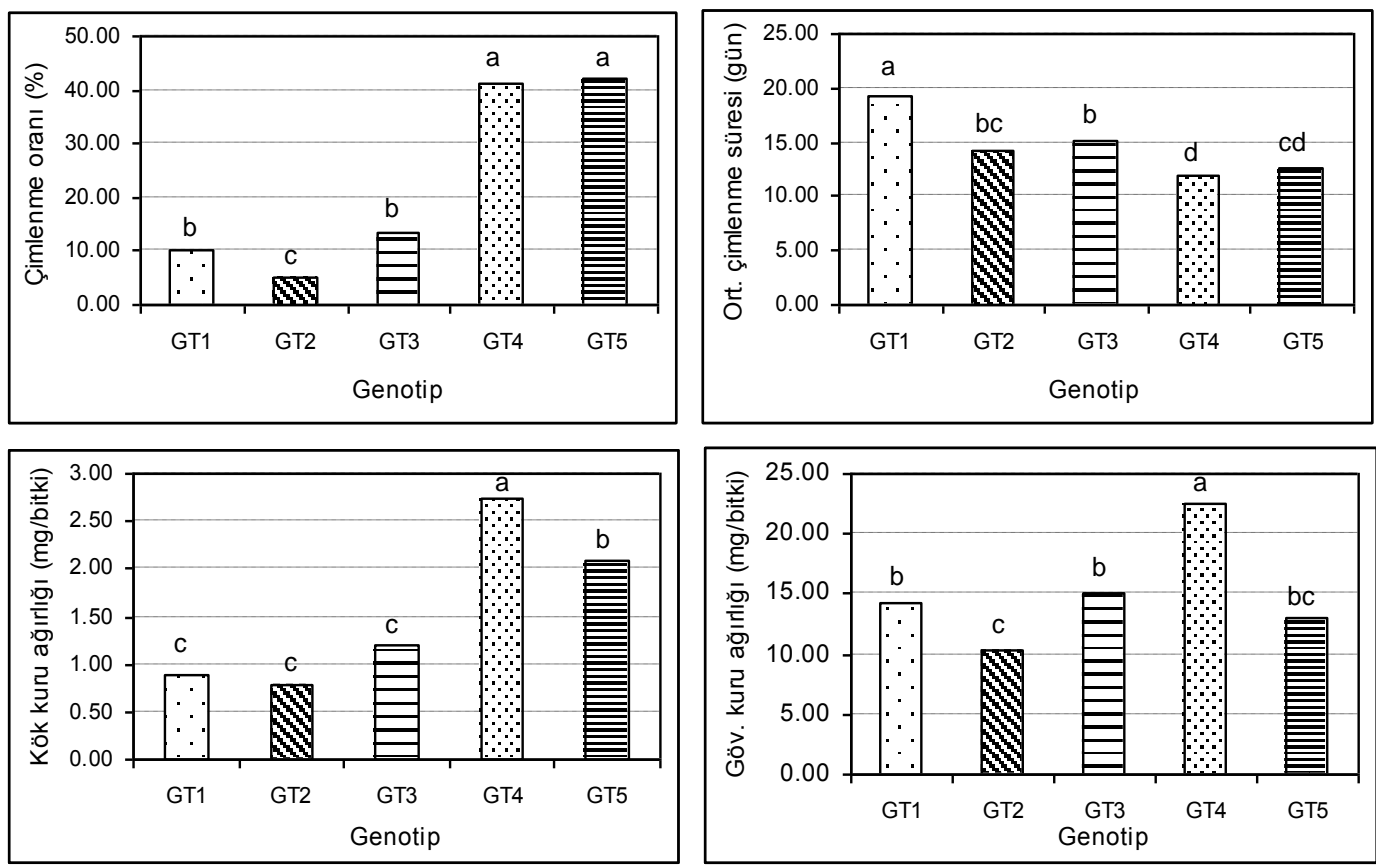

Şekil 2. C. australis tohumlarının çimlenme özelliklerine genotipin ana etkisi. Her bir özellik grafiğinde farklı harflerle gösterilen ortalamalar \% 5 önem düzeyindeki Duncan testine göre birbirinden farklıdır.

Figure 2. The main effect of genotype on germination characteristics of $C$. australis seeds. Means indicated by different letters in each characteristic graph are significantly different at the $5 \%$ level according to Duncan's multiple range.
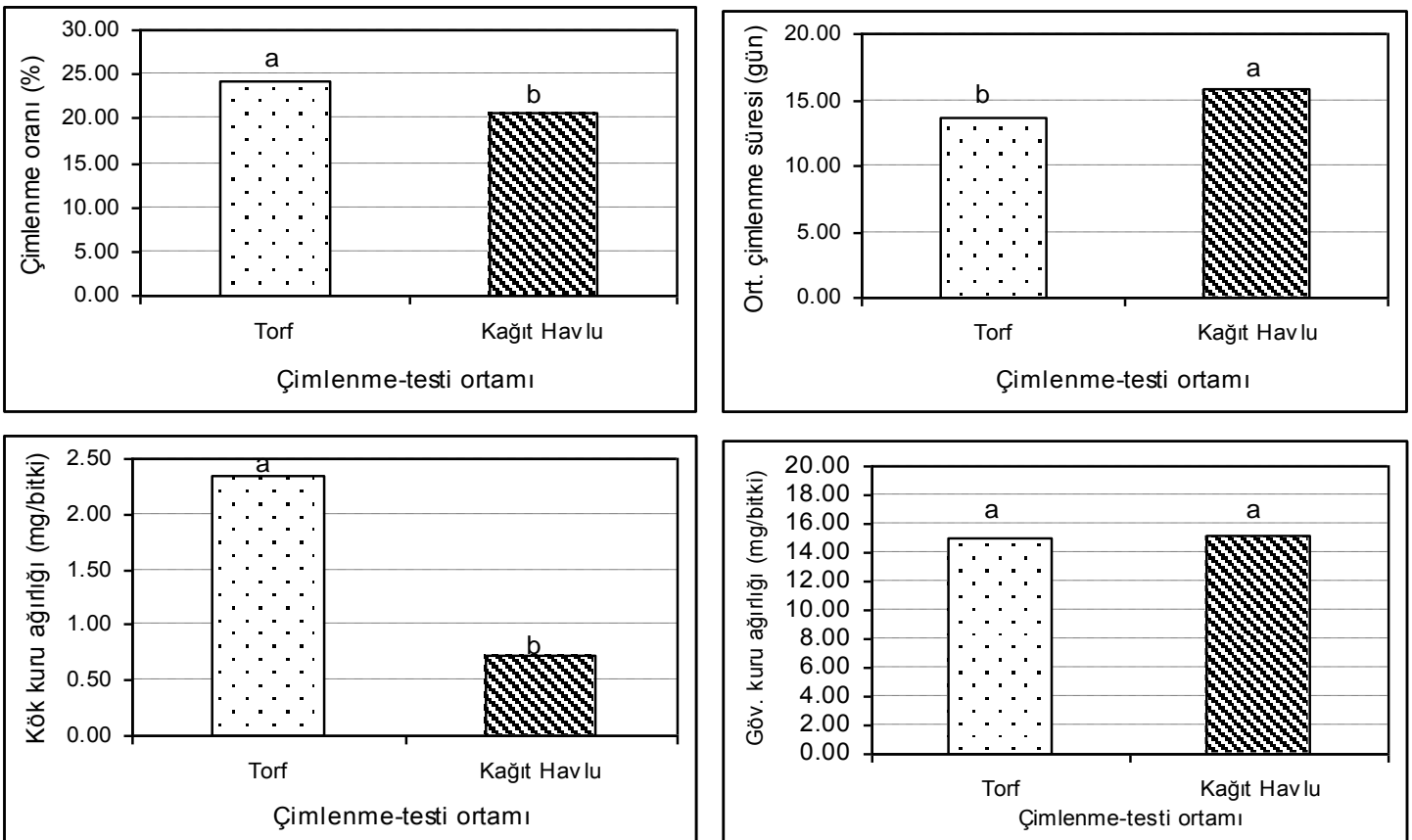

Şekil 3. C. australis tohumlarının çimlenme özelliklerine çimlenme-testi ortamının ana etkisi. Her bir özellik grafiğinde farklı harflerle gösterilen ortalamalar \%5 önem düzeyindeki Duncan testine göre birbirinden farklıdır.

Figure 3. The main effect of germination-test medium on germination characteristics of $C$. australis seeds. Means indicated by different letters in each characteristic graph are significantly different at the $5 \%$ level according to Duncan's multiple range.

C. australis tohumlarında temel tohum özellikleri ile çimlenme özellikleri arasındaki ilişkiler ve istatistiksel değerlendirmeleri Çizelge 4'de sunulmuştur. Korelasyon analizi, tohum çapı ile tohum ağırlığı, ortalama kök ve gövde kuru ağırlıkları arasında, tohum ağırlığı ile tohum çapı, ortalama çimlenme oranı, ortalama kök ve gövde kuru ağırlıkları arasında istatistiksel anlamda önemli ve pozitif ilişkilerin olduğunu ortaya koymuştur (Çizelge 4). Ortalama çimlenme oranı ile kök ve gövde kuru ağırlığı değerleri ve ortalama kök kuru ağırlığı ile gövde kuru ağırlığı arasında da önemli ve pozitif ilişkiler belirlenmiş, özellikler arasında önemli ve negatif ilișki görülmemiştir (Çizelge 4). 
Çizelge 3. C. australis tohumlarının çimlenme özelliklerine katlama (stratifikasyon) süresi, genotip ve çimlenme-testi ortamı interaksiyonlarının etkileri.

Table 3. Effects of stratification time, genotype and germination-test medium interactions on germination characteristics of $C$. australis seeds.

\begin{tabular}{|c|c|c|c|c|c|}
\hline \multirow[b]{2}{*}{ Özellik } & \multirow[b]{2}{*}{ Genotip } & \multirow[b]{2}{*}{ Çimlenme-testi Ortamı } & \multicolumn{3}{|c|}{ Katlama Süresi (gün) } \\
\hline & & & 0 & 60 & 90 \\
\hline \multicolumn{6}{|c|}{ Çimlenme oranı (\%) } \\
\hline & GT1 & Torf & $0.00 \mathrm{~A}^{\mathrm{y}} \mathrm{b}^{\mathrm{z}}$ & 2.67 Bab & $21.35 \mathrm{Aa}$ \\
\hline & & Kağıt Havlu & $0.00 \mathrm{Ab}$ & $21.33 \mathrm{Aa}$ & $14.67 \mathrm{Bab}$ \\
\hline & GT2 & Torf & $0.00 \mathrm{Ab}$ & $0.00 \mathrm{Ab}$ & $21.33 \mathrm{Aa}$ \\
\hline & & Kağıt Havlu & $0.00 \mathrm{Ab}$ & $0.00 \mathrm{Ab}$ & $8.00 \mathrm{Ba}$ \\
\hline & GT3 & Torf & $0.00 \mathrm{Ac}$ & $16.00 \mathrm{Ab}$ & $24.00 \mathrm{Aa}$ \\
\hline & & Kağıt Havlu & $0.00 \mathrm{Ac}$ & $22.17 \mathrm{Aa}$ & $17.33 \mathrm{Ab}$ \\
\hline & GT4 & Torf & $0.00 \mathrm{Ab}$ & $66.67 \mathrm{Aa}$ & $73.33 \mathrm{Aa}$ \\
\hline & & Kağıt Havlu & $0.00 \mathrm{Ac}$ & $37.33 \mathrm{Bb}$ & $69.33 \mathrm{Aa}$ \\
\hline & GT5 & Torf & $0.00 \mathrm{Ab}$ & $61.33 \mathrm{Aa}$ & $74.67 \mathrm{Aa}$ \\
\hline & & Kağıt Havlu & $0.00 \mathrm{Ab}$ & $49.33 \mathrm{Aa}$ & $68.00 \mathrm{Aa}$ \\
\hline \multicolumn{6}{|c|}{$\begin{array}{l}\text { Ortalama çimlenme süresi } \\
(\text { gün })^{x}\end{array}$} \\
\hline & GT1 & Torf & - & $23.50 \mathrm{Aa}$ & $14.78 \mathrm{Ab}$ \\
\hline & & Kağıt Havlu & - & $21.22 \mathrm{Aa}$ & $17.94 \mathrm{Aa}$ \\
\hline & GT2 & Torf & - & - & $13.37 \mathrm{~A}$ \\
\hline & & Kağıt Havlu & - & - & $14.87 \mathrm{~A}$ \\
\hline & GT3 & Torf & - & $15.53 \mathrm{Aa}$ & $12.27 \mathrm{Ba}$ \\
\hline & & Kağıt Havlu & - & $17.34 \mathrm{Aa}$ & $15.29 \mathrm{Aa}$ \\
\hline & GT4 & Torf & - & $11.98 \mathrm{Ba}$ & $8.62 \mathrm{Ba}$ \\
\hline & & Kağıt Havlu & - & $16.07 \mathrm{Aa}$ & $11.23 \mathrm{Ba}$ \\
\hline & GT5 & Torf & - & $12.36 \mathrm{Aa}$ & $10.11 \mathrm{Aa}$ \\
\hline & & Kağıt Havlu & - & $14.67 \mathrm{Aa}$ & $12.97 \mathrm{Aa}$ \\
\hline \multicolumn{6}{|c|}{ Kök kuru ağırlı̆̆ (mg) } \\
\hline & GT1 & Torf & $0.00 \mathrm{Ab}$ & $1.60 \mathrm{Aa}$ & $3.15 \mathrm{Aa}$ \\
\hline & & Kağıt Havlu & $0.00 \mathrm{Aa}$ & $0.22 \mathrm{Aa}$ & $0.37 \mathrm{Ba}$ \\
\hline & GT2 & Torf & $0.00 \mathrm{Ab}$ & $0.00 \mathrm{Ab}$ & $3.73 \mathrm{Aa}$ \\
\hline & & Kağıt Havlu & $0.00 \mathrm{Aa}$ & $0.00 \mathrm{Aa}$ & $1.03 \mathrm{Ba}$ \\
\hline & GT3 & Torf & $0.00 \mathrm{Ab}$ & $3.01 \mathrm{Aa}$ & $0.35 \mathrm{Bb}$ \\
\hline & & Kağıt Havlu & $0.00 \mathrm{Ab}$ & $0.88 \mathrm{Bb}$ & $2.98 \mathrm{Aa}$ \\
\hline & GT4 & Torf & $0.00 \mathrm{Ab}$ & $6.95 \mathrm{Aa}$ & 6.21 aа \\
\hline & & Kağıt Havlu & $0.00 \mathrm{Ab}$ & $1.03 \mathrm{Ba}$ & $2.00 \mathrm{Ba}$ \\
\hline & GT5 & Torf & $0.00 \mathrm{Ab}$ & $5.94 \mathrm{Aa}$ & $4.36 \mathrm{Aa}$ \\
\hline & & Kağıt Havlu & $0.00 \mathrm{Aa}$ & $1.10 \mathrm{Ba}$ & $1.11 \mathrm{Ba}$ \\
\hline \multicolumn{6}{|c|}{ Gövde kuru ağırlığı (mg) } \\
\hline & GT1 & Torf & $0.00 \mathrm{Ab}$ & $13.83 \mathrm{Aa}$ & $24.74 \mathrm{Aa}$ \\
\hline & & Kağıt Havlu & $0.00 \mathrm{Ab}$ & $19.80 \mathrm{Aa}$ & $27.69 \mathrm{Aa}$ \\
\hline & GT2 & Torf & $0.00 \mathrm{Ab}$ & $0.00 \mathrm{Ab}$ & $31.56 \mathrm{Aa}$ \\
\hline & & Kağıt Havlu & $0.00 \mathrm{Ab}$ & $0.00 \mathrm{Ab}$ & $29.82 \mathrm{Aa}$ \\
\hline & GT3 & Torf & $0.00 \mathrm{Ab}$ & $20.53 \mathrm{Aa}$ & $26.55 \mathrm{Aa}$ \\
\hline & & Kağıt Havlu & $0.00 \mathrm{Ab}$ & $22.97 \mathrm{Aa}$ & $20.42 \mathrm{Aa}$ \\
\hline & GT4 & Torf & $0.00 \mathrm{Ab}$ & $37.28 \mathrm{Aa}$ & $36.10 \mathrm{Aa}$ \\
\hline & & Kağıt Havlu & $0.00 \mathrm{Ab}$ & $36.45 \mathrm{Aa}$ & $25.52 \mathrm{Ba}$ \\
\hline & GT5 & Torf & $0.00 \mathrm{Ab}$ & $16.88 \mathrm{Aa}$ & $23.25 \mathrm{Aa}$ \\
\hline & & Kağıt Havlu & $0.00 \mathrm{Ab}$ & 18.17 Aa & $20.32 \mathrm{Aa}$ \\
\hline
\end{tabular}

x: Analizler çimlenme olmayan uygulamalar çıkarılarak gerçekleștirilmiștir.

y: Her çimlenme özelliği, genotip ve çimlenme-testi ortamı (sütun) içinde farklı büyük harflerle gösterilen ortalamalar \% 5 önem düzeyinde Duncan testine göre birbirinden farklıdır.

z: Her çimlenme özelliği, genotip, çimlenme-testi ortamı ve katlama süresi (satır) içinde farklı küçük harflerle gösterilen ortalamalar \%5 önem düzeyinde Duncan testine göre birbirinden farklıdır. 
Çizelge 4. C. australis tohumlarında tohum ve çimlenme özellikleri arasındaki ilişkiler (korelasyonlar).

Table 4. Correlations between seed and germination characteristics of $C$. australis seeds.

\begin{tabular}{lcccc}
\hline Özellik & TA & TÇ & OÇO & OÇS \\
\hline TÇ & $\mathbf{0 . 9 2 3}$ & & \\
OÇO & $<\mathbf{0 . 0 0 1}$ & & \\
& $\mathbf{0 . 5 4 6}$ & 0.507 & \\
OÇS & $\mathbf{0 . 0 3 5}$ & 0.054 & -0.383 & 0.159 \\
& -0.463 & -0.350 & $\mathbf{0 . 9 3 3}$ & -0.498 \\
OKKA & 0.082 & 0.200 & $<\mathbf{0 . 0 0 1}$ & 0.059 \\
& $\mathbf{0 . 6 7 3}$ & $\mathbf{0 . 6 6 9}$ & $\mathbf{0 . 5 6 1}$ & -0.361 \\
OGKA & $\mathbf{0 . 0 0 6}$ & $\mathbf{0 . 0 0 6}$ & $\mathbf{0 . 0 3 0}$ & 0.187 \\
& $\mathbf{0 . 5 4 2}$ & $\mathbf{0 . 6 3 3}$ & $\mathbf{0 . 7 1 5}$ & $\mathbf{0 . 0 0 3}$ \\
\hline
\end{tabular}

TA: Tohum ağırlığı; TÇ: Tohum çapı; OÇO: Ortamla çimlenme oranı; OÇS: Ortalama çimlenme süresi; OKKA: Ortalama kök kuru ağılığı; OGKA: Ortalama gövde kuru ağırlığı. İstatistiksel anlamda önemli olan ilişkiler (korelasyonlar) koyu, $P$ değerleri ise italik yazılmıştır.

\section{Tartışma ve Sonuç}

Bu çalışmadan elde edilen sonuçlar, Antalya ili Serik ilçesindeki $C$. australis genotipleri tohumlarının soğuklama ihtiyacı niteliğindeki fizyolojik dormansiye sahip olduklarını, bu nedenle katlama (stratifikasyon) uygulanmadan nispeten yüksek toprak sıcaklığı şartlarına yapılan ekimlerden tatmin edici düzeyde çimlenme oranlarının elde edilmesinin çok güç olduğunu göstermiştir.

Çalışma ile belirlenen tohum çap ve ağırlık değerleri Juan ve ark. (2006)'nın çalışmalarında elde ettiği tohum çap (0.154 \pm $0.038 \mathrm{mg}$ ) ve ağırlık (minimum $6.38 \mathrm{mg}$, maksimum $7.41 \mathrm{mg}$ ) değerleri ile benzerlik göstermektedir. Sonuçlar, tohum kaynağının $C$. australis tohumlarının morfolojik özelliklerini büyük ölçüde etkilediğini saptayan Singh ve ark. (2006)'nın çalışması ile de paralellik sergilemektedir. Öte yandan odunsu bitki türlerinde tohum morfolojik ve fizyolojik özelliklerinin meyvelerin bitki üzerinde bulundukları konuma bağlı olarak dahi farklılık gösterebildiği (Nielsen 1988) bilinmektedir.

Farklı sürelerdeki katlama uygulamaları C. australis tohumlarının çimlenme oranını arttırmıştır. Bu sonuç Hartmann ve ark. (2002), Takos ve Efthimiou (2002), APAT (2003), Dirr ve Heuser (2006) ve Ballesteros ve ark. (2015)'nın bulgu, yorum ve önerileriyle uyum göstermektedir. $\mathrm{Bu}$ önerilerin büyük çoğunluğunda $C$. australis tohumlarının soğuk mevsimde açığa ekilmeleri aksi halde katlama uygulamalarına ihtiyaç olduğu açıkça bildirilmektedir. $\mathrm{Bu}$ çalışmada kullanılan genotipler Akdeniz kıyı kesimi doğal bitkileri olmalarına rağmen aynı kesinlikte fizyolojik dormansiye sahip oldukları açık delilleriyle ortaya çıkmıştır. Öte yandan bazı deliller ve son yıllarda elde edilen araştırma sonuçları (Güney ve ark. 2018) aslında $C$. australis türünde dormansinin ortadan kalması için ihtiyaç duyulan düşük sıcaklığın derecesinin bilinen klasik +4$5^{\circ} \mathrm{C}$ civarında değil nispeten daha yüksek dereceler olabileceği ihtimalini kuvvetlendirmektedir. Nitekim Hamada ve Tanaka (1988) benzer bir durumu Prunus lannesiana Wils. (Carr.) var. speciosa'da araştırmışlar ve en iyi çimlenme sonuçlarını 3$4^{\circ} \mathrm{C}$ 'de $12-16$ hafta, $8-9^{\circ} \mathrm{C}$ 'de ise 12 hafta 1 slak katlama yapilan tohumlardan elde etmişlerdir. Benzer bir biyolojik özelliğin $C$. australis tohumları için geçerliliğinin araştırılmasına ihtiyaç bulunmaktadır.

Bu çalışmada incelenen hemen tüm çimlenme özelliklerinde genotipten kaynaklanan önemli farklılıkların olduğu belirlenmiştir. Örneğin GT4 ve GT5 genotiplerinde Takos ve Efthimiou (2002)'nun bildirdiği çimlenme oranlarına benzer sonuçlar alınırken, GT1, GT2 ve GT3 genotiplerinde ise daha düşük oranlarda çimlenme gerçekleşmiştir. Bu sonuç, çimlenme yetenekleri bakımından genotipler arasındaki genetik farkı işaret etmekte ve buna benzer çok sayıda çimlenme davranışının varlığı bilimsel bir gerçeklik olarak kabul görmektedir (Otho ve ark. 2007; Elias ve ark. 2012; Baskin ve Baskin 2014).

Çimlenme-testi ortamlarının daha çok laboratuar teknik testleri ve tohumculuk teknolojisinin teknik araçlarından kabul edilmeleri yaygin bir durumdur (Elias ve ark. 2012). Baskin ve Baskin (2014) çimlenme denemelerinde birçok ortam kullanılabildiğini ve türlerin bu ortamlara farklı tepkiler verebildiğini bildirmektedirler. Prasad ve ark. (1996) Litchi chinensis ve Lee ve Yang (1999) ise Lilium formosanum'un tohumlarında çimlenme oranlarının çimlenme-testi ortamına göre farklılaştı̆̆ını kanıtlamışlardır. C. australis türünde de torf ortamında kağıt havlu ortamına kıyasla daha iyi çimlenme özelliği sonuçları alınmıştır.

$\mathrm{Bu}$ çalışmadan elde edilen sonuçlar, Baskin ve Baskin (2004)'in dormansiyi sınıflandırma kriterleri esas alındığında Akdeniz kıyı kesimi $C$. australis genotipleri tohumlarında fizyolojik dormansi varlığının kanıtı olarak değerlendirilmiştir. Ayrıca dormansinin ortadan kaldırılması için en uygun nispeten yüksek sıcaklık derecelerinin araştırılmasına ihtiyaç olduğu düşünülmektedir.

\section{Teşekkür}

Bu çalışma FYL-2014-173 proje numarasıyla Akdeniz Üniversitesi Bilimsel Araştırma Projeleri Koordinasyon Birimi tarafından desteklenmiş olan yüksek lisans tezinin bir bölümüdür.

\section{Kaynaklar}

APAT (Agency for the protection of the environment and for technical services) (2003) Seed Propagation of Mediterranean Trees and Shrubs. IGER, Roma.

Ballesteros D, Meloni F, Bachetta G (Eds) (2015) Manual for the Propagation of Selected Mediterranean Plants Species. Ecoplantmed, ENPI, CBC-MED, Cagliari.

Baskin JM, Baskin CC (2004) A classification system for seed dormancy. Seed Science Research 14: 1-16.

Baskin CC, Baskin JM (2014) Seeds Ecology, Biogeography and Evolution of Dormancy and Germination, Second Edition. Academic Press, San Diego.

Brzuszek RF, Harkess RL (2009) Green industry survey of native plant marketing in the Southeastern United States. HortTechnlogy 19(1): 168-172. 
Copeland LO, McDonald MB (2001) Principles of Seed Science and Technology, $4^{\text {th }}$ Edition. Springer Science+Business Media, New York.

Crivellaro A, Schweingruber FH (2013) Atlas of Wood, Bark and Pith Anatomy of Eastern Mediterranean Trees and Shrubs- With a special focus on Cyprus. Springer, Berlin.

Dirr MA, Heuser CW (2006) The Reference Manual of Woody Plant Propagation-From Seed to Tissue Culture. Varsity Press, North Carolina.

Elias SG, Copeland LO, McDonald MB (2012) Seed Testing-Principles and Practices. Michigan State University Press, Michigan.

Güney D, Turna İ, Atar F (2018) The effects of different pretreatments on germination of Mediterranean hackberry (Celtis austarlis L.) seeds. Biological Diversity and Conservation 11(1): 61-67.

Hamada Y, Tanaka TO (1988) Effects of low temperature and storage periods for seed dormancy release on Prunus lannesiana Wils. (Carr.) var. speciosa. Acta Horticulturae 226: 541-548.

Hartmann HT, Kester DE, Davies FT, Geneve, RL (2002) Hartmann and Kester's Plant Propagation, Principles and Practices. Prentice Hall, New Jersey.

Idzojtic M (2019) Dendrology-Cones, flowers, fruits and seeds. Academic Press (Elsevier), London.

Juan T, Sagrario A, Jesus H, Cristina CM (2006) Red fox (Vulpes vulpes L.) favour seed dispersal, germination and seedling survival of Mediterranean hackberry (Celtis australis L.). Actaoecologica 30: 39-45.

Karagüzel O (2003) Farklı tuz kaynak ve konsantrasyonlarının güney anadolu doğal Lupinus varius'larının çimlenme özelliklerine etkisi. Akdeniz Üniversitesi Ziraat Fakültesi Dergisi 16(2): 211-220.

Kayacık H (1977) Orman ve Park Ağaçlarının Özel Sistematiği, II. Cilt. İstanbul Üniversitesi, Orman Fakültesi, İstanbul.

Lee YJ, Yang CM (1999) Effects of temperature and substrate medium on seed germination of Lilium formosanum Wall. Journal of Agricultural Association of China (New Series) 187: 10-18.
Nielsen KK (1988) Dormancy in seeds from different positions on individual plants. Acta Horticulturae 226: 255-261.

Otho M, Stone SL, Harada JJ (2007) Genetic control of seed development and seed mass. In: Bradford K, Nonogaki H (Eds), Seed Development, Dormancy and Germination, Annual Plant Reviews Volume 27, Blackwell Publishing, Iowa.

Pipinis P, Milios E, Mavrokordopoulou O, Smiris P (2018) Effect of sowing date on seedling emergence of species with seeds enclosed in a stony endocarp. Journal of Sustainable Forestry 37(4): 375388 .

Prasad JS, Kumar R, Mishra M, Kumar R, Singh AK, Prasad US (1996) Characteristics of litchi seed germination. HortScience 31: 11871189.

Singh B, Bhatt BP, Prasad P (2006) Variation in seed and seedling traits of Celtis australis: A multipurpose tree in Central Himalaya, India. Agroforestry Systems 67: 115-122.

Singh B, Bhatt BP, Prasad P (2009) Effects of storage period on seed germination of Celtis australis L. in Central Himalaya, India. Indian Journal of Agroforestry 11(2): 62-65.

Takos IA, Efthimiou GSP (2002) Germination result on dormant seeds of fifteen tree species- Autumn sown in a Northern Greek nursery. Silvae Genetica 52(2): 67-71.

von Henting WU (1998) Strategies of evaluation and introduction of new ornamental plants. Acta Horticulturae 454: 65-80.

Yaltırık F, Efe A (2000) Dendroloji Ders Kitab1, GymnospermaeAngiospermae. İstanbul Üniversitesi Orman Fakültesi Yayınları, İstanbul.

Yücedağ C, Gültekin HC (2008) Adi çitlenbik (Celtis australis L.) ve doğu çitlenbiği (Celtis tournefortii Lam.) tohumlarının çimlenmesi üzerine araştırmalar. Süleyman Demirel Üniversitesi, Fen Bilimleri Enstitüsü Dergisi 12(3): 182-185. 